\title{
Wheat Yield Responses to Rising Temperature: Insights from North Indian Plains of India
}

\section{Philip Kuriachen}

ICAR-Indian Agricultural Research Institute

\section{Asha Devi}

ICAR-Indian Agricultural Research Institute

\section{Anu Susan Sam}

Regiional Agricultural Research Station

\section{Suresh Kumar}

Research centre, ICAR-Indian Institute of Soil and Water Conservation

Jyoti Kumari

Division of Germplasm Evaluation

\section{A Suresh}

ICAR-Central Institute of Fisheries Technology

Girish Kumar Jha ( $\boldsymbol{\nabla}$ girish.stat@gmail.com )

Indian Agricultural Research Institute https://orcid.org/0000-0002-3872-4843

\section{Research Article}

Keywords: Climate change impact, wheat, panel data, agricultural policy Indo-Gangetic plains

Posted Date: September 8th, 2021

DOI: https://doi.org/10.21203/rs.3.rs-699747/v1

License: (c) (i) This work is licensed under a Creative Commons Attribution 4.0 International License.

Read Full License 
7

\section{Wheat Yield Responses to Rising Temperature: Insights from North Indian Plains of India}

Philip Kuriachen ${ }^{1}$, Asha Devi, S. $S^{2}$, Anu Susan Sam, ${ }^{3}$ Suresh Kumar ${ }^{4}$, Jyoti Kumari ${ }^{5}$, A. Suresh ${ }^{6}$, Girish K. Jha ${ }^{7 *}$

\section{Authors List}

1. Philip Kuriachen

Phd Scholar

Division of Agricultural Economics

ICAR-Indian Agricultural Research Institute

New Delhi - 110012, INDIA

Email: philipkuriachen@gmail.com

2. Asha Devi, S.S

Scientist

Division of Agricultural Economics

ICAR-Indian Agricultural Research Institute

New Delhi - 110012, INDIA

Email:ash.nibha@gmail.com

3. Anu Susan Sam

Assistant Professor (Agricultural Economics)

Kerala Agricultural University,

Regiional Agricultural Research Station,

Kumarakom, Kottayam,Kerala,686563, India

Email:anu.susan@kau.in

4. Suresh Kumar

Scientist

Research centre, ICAR-Indian Institute of Soil and Water Conservation

Koraput,Odisha, INDIA

Email:skdagri@gmail.com

5. Jyoti Kumari

Principal Scientist

Division of Germplasm Evaluation

ICAR-NBPGR

New Delhi - 110012, INDIA

Email: jj.gene@gmail.com

6. A. Suresh

Principal Scientist

ICAR-Central Institute of Fisheries Technology

Cochin-682029, INDIA

Email: sureshcswri@gmail.com

7. Girish K. Jha

Principal Scientist

Division of Agricultural Economics

ICAR-Indian Agricultural Research Institute

New Delhi - 110012, INDIA

Email: girish.stat@gmail.com

*Corresponding author 
3 Climate change and consequent variations in temperature pose a significant challenge for sustaining wheat 4 production systems globally. In this study, the potential impact of rising temperature on wheat yield in the north 5 Indian plains, India's major wheat growing region, was analyzed using panel data from the year 1981 to 2009. 6 This study deviates from the majority of the previous studies by including non-climatic factors in estimating the 7 impact of climate change. Two temperature measures were used for fitting the function, viz., Growing Season 8 Temperature (GST) and Terminal Stage Temperature (TST), to find out the differential impact of increased 9 temperature at various growth stages. Analysis revealed that there was a significant rise in both GST as well as 10 TST during the study period. The magnitude of the annual increment in TST was twice that of GST. Wheat 11 yield growth in the region was driven primarily by increased input resources such as fertilizer application and technological development like improved varieties and management practices. Most importantly, the study found that the extent of yield reduction was more significant for an increase in temperature at terminal crop growth stages. The yield reduction due to unit increase in TST was estimated to be $2.26 \%$ while rise in GST by $1^{\circ} \mathrm{C}$ resulted in yield reduction of $2.03 \%$.

Key words: Climate change impact, wheat, panel data, agricultural policy Indo-Gangetic plains, 
2 Worldwide, climate change is manifested in the form of rising surface temperatures, increase in frequency and intensity of heatwaves, prolonged drought spells, variation in precipitation etc. (Schiermeir 2018; Im et al. 2017; Schubert et al. 2016; Fant et al. 2016; Burt 2016; IPCC 2007, 2014). Global agriculture production has been significantly affected by climate change (Ochieng et al. 2016; Howden et al. 2007; Kato et al. 2011; Vermueleun et al. 2012). Due to high dependence on various weather parameters, agriculture is highly vulnerable to changing climate (Yu et al. 2014; Ahmed et al. 2018). Rainfall and temperature are the most important weather parameters affecting agriculture. Any variation in these parameters will increase the variability in production and also lead to yield reduction (Richardson et al. 2018; Nelson et al. 2014; Wheeler and von Braun 2013; Houser et al. 2015). Crop production systems in developing countries are impacted the most by this climate change, and they are less equipped to afford its consequences (Vermuelen et al. 2012; Gornall et al. 2010; Parker et al. 2019).

India being a developing nation is highly vulnerable to changing climate. The main reasons for this high vulnerability are greater dependence of its population on agriculture, relatively smaller landholdings, and the lack of adequate financial resources, technology, and institutions to cope with the adverse effects of such shocks (Rao et al. 2011). Climate change has enhanced the food insecurity issues of already vulnerable people in India. Although since 1990, the country has witnessed a rapid growth of economy (Narayanan, 2015), yet, it is home to more than 300 million poor people and 194.6 million undernourished individuals (Bhuyan et al 2020). Climate change directly affects agricultural production, while it indirectly affects economic growth and income distribution (Amjath-Babu et al. 2016; Hossain et al. 2019). As per the predictions, India's population is expected to reach 1.8 billion by 2050 and to feed this huge population, more food grains are needed to be produced from declining per capita arable land and irrigation water resources and expanding climatic variability (Swaminathan, 2013). Currently, India produces about 291 million tonnes of cereals to feed 1.15 billion populations and it has to be doubled by 2050 in order to meet the needs of the expected population (Government of India, 2020). Hence, it is essential to increase food supplies while combating climate variability in order to meet the food requirements of fast-growing populations in India.

Among cereals, wheat plays a critical role in India's food security. India produces 102.19 million tonnes of wheat from a total area of about 29.14 million hectares (GoI, 2019). Indian population consumes approximately 65 million tonnes of wheat annually, ranking it as the second-largest consumer of wheat in the world (Tripathi and Mishra 2017). Globally, India stands second in wheat production and it accounts for about 13.18 percent of world's wheat production as of 2019-20 (MoA\&FW 2019). India exports 0.23 million tonnes of wheat annually (GoI 2019). In India, wheat is cultivated mainly in Indo-Gangetic Plains (IGP) (Tripathi \& Mishra, 2017; Rao et al. 2015) and it is grown as rabi ${ }^{1}$ crop. It is sown during the months of October - November and harvested during February - April (Dhamija et al. 2020). The ideal average daily temperature for wheat crop ranges from 20 to $25^{\circ} \mathrm{C}$ (Tripathi \& Mishra, 2017). Wheat crop is highly susceptible to temperature variations during various growth stages, especially at the anthesis and grain filling stages (Asseng et al. 2011; Asseng et al. 2015; Lobell

\footnotetext{
${ }^{1}$ In India cropping is done in three seasons namely Kharif (monsoon season crop), Rabi (winter season crop) and Zaid (summer season crop).
} 
et al. 2011; Tack et al. 2015). Deryng et al. (2014) reported that temperature between 25 to $35^{\circ} \mathrm{C}$ cause heat stress for wheat plant growth, especially during the grain formation stage. Daily average temperature above 35 ${ }^{\circ} \mathrm{C}$ is detrimental for wheat plant.

In recent years, temperature extremes caused a considerable wheat yield reduction (Aggarwal, 2008; Aggarwal et al. 2010; Subash and Mohan, 2012). In India, the wheat yield loss for every $1{ }^{\circ} \mathrm{C}$ rise in temperature was estimated to be 4 to 5 million tonnes (Aggarwal 2008). In IGP region, delay in the harvest of rice crop resulted in the late sowing of wheat and this led to wheat yield loss due to the high temperature at grain filling stage (Dwivedi et al. 2017). The current temperature rise has reduced the wheat yields up to 5 percent (Gupta et al. 2017). The future weather predictions of the IGP region show that wheat farming may not be suitable in this region due to heat stress (Mahmood et al. 2019). It is estimated that increase in global mean temperature by one degree-Celsius would reduce global wheat yield of by 6 percent (Zhao et al. 2017). By 2050, the annual mean temperature of India will rise by $1.5-3^{\circ} \mathrm{C}$ and this could have a damaging effect on the future wheat cultivation (Mani et al. 2018). The negative impact of rising average temperature on wheat production remains as the main concern for future food security.

The potential impact of global warming on wheat yields has been investigated extensively using crop simulation models (Lal et al. 1998; Attri and Rathore 2003; Kumar et al. 2014; Zacharias et al. 2014). However, simulation models subject to uncertainties in parameter values that further enhance uncertainties in the projected impact of climate change (Lobell and Burke 2010). Additionally, these models are excessively reliant on field calibration of data and lack flexibility in their application for analyzing impacts at larger scales. Statistical models have been used as alternatives to data-intensive simulation models due to greater transparency regarding model uncertainties and lower reliance on field calibration of data (Lobell and Burke 2010). In India, only a few studies have used historical data to estimate statistical models for analyzing the impact of climate change (Birthal et al. 2014; Jha and Tripathi 2017). However, these studies failed to account for a complete range of inputs used or technological changes, which often disallows the possibility of segregating climate change from other factors like input intensification and improved crop management, which have a sizable influence on crop yield (Zhai et al. 2017, You et al. 2009). Whereas in few studies conducted in India, the researchers considered a more comprehensive range of inputs for obtaining more accurate representation of climate response functions (You et al. 2009; Holst et al. 2013, Pattanayak and Kumar 2014). In the Indian context, specifically for wheat crop existing literature using statistical models have failed to segregate the effect of climatic and non-climatic factors on crop yields. Therefore, this study aims to estimate the impact of rising temperature on wheat yields after segregating the effect of non-climatic factors. More specifically we use a crop specific state level panel data to estimate response functions of wheat yield to rising temperature after controlling for input use and technological change.

\section{Data and methods}

\subsection{Study Area}

(Insert Fig 1 here) 
In this study, we have selected the major wheat cultivating states in India viz; Punjab, Haryana, Uttar Pradesh, Bihar and Rajasthan (Figure 1). Except Rajasthan, all other states spread across IGP. IGP is known as 'the food bowl of India' and this region consists of states such as Punjab, Haryana, Uttar Pradesh, Bihar and West Bengal. The IGP consists of two drainage basins, western part drains to Indus and eastern part comprises the GangesBrahmaputra drainage systems and hence, it is one of the world's most intensively cultivated area (Sehgal et al, 2013). Rice and wheat are the two major crops cultivated in this area. The four states in the IGP selected for the study hold 60.81 percent of total area under wheat cultivation and contribute 68.21 percent of total wheat production in the country, while Rajasthan holds a share of over 10 percent in both area and production in the year 2018-19 (GoI,2019). Though West Bengal belongs to IPG region, wheat cultivation is very less in this state and hence it was not considered for the present study.

\subsection{Data description}

The state-level data of five major wheat-growing states in the IGP viz., Punjab, Haryana, Rajasthan, Uttar Pradesh, and Bihar for the period 1981 to 2009 was used for this study. Yield data was obtained from the Department of Economics and Statistics' annual publications, Government of India (GOI). Data regarding input usage for wheat cultivation were compiled from various issues of the Comprehensive Scheme of Cost of Cultivation published by the Directorate of Economics and Statistics, GOI. Wheat yield was measured in kilogram per hectare $(\mathrm{kg} / \mathrm{ha})$, and all crop inputs except chemical fertilizer were measured as expenses per hectare at 2004-05 prices (Rupees per hectare), whereas application of fertilizers was measured in $\mathrm{kg} / \mathrm{ha}$. Further, missing values were imputed using a spline function for the respective states.

The data on climate variables were extracted from 1 x 1 degree daily gridded data obtained from the Indian Meteorological Department, Pune. The daily data on maximum and minimum temperatures were transformed into average season temperature for the crop growing period. Wheat is cultivated in India mostly during Rabi (winter) season, with a growing period spanning between October-December and March-April. However, there are slight variations in crop growing periods across regions depending upon weather and cropping pattern. The variation in growing season across the country was accounted for in calculating average Growing Season Temperature (GST) for different states. Among various climatic variables, rainfall was excluded as most of the wheat-growing areas in IGP were irrigated. The share of the irrigated area to the total cultivated wheat area increased rapidly in IGP over a period of time (Zaveri and Lobell 2019). The proportion of wheat grown area under irrigation varied between 95.7 percent in Bihar to 99.7 percent in Rajasthan during 2015-16 (GoI 2019). Wheat yield is adversely affected by terminal heat stress, especially under delayed sowing conditions (Nagarajan 2005; Spiertz 2006; Singh et al. 2011). The flowering and grain filling stages are thus highly susceptible to heat stress. Hence, to determine the extent of variation in crop yield due to change in temperature at terminal stages of crop growth, separate measure referred to as Terminal Stage Temperature (TST) was computed by taking average temperature during March to April.

\subsection{Methods}

\subsubsection{Trend Estimation}


Mann- Kendall statistic and Sen's slope estimator were used for examining the trends in average GST and

2 average TST. Non-parametric tests are preferred to conventional parametric methods because the former is more

3 powerful when probability distribution is skewed (Onoz and Bayazit 2003). Mann-Kendall statistic is a non-

4 parametric way of identifying trends in time series data wherein the significance of trend is tested based on

5 normalized test statistic (Z-values). This test is commonly used to determine the direction of the trend and

6 whether it is increasing or decreasing based on signs of the $\mathrm{Z}$ values. A positive $\mathrm{Z}$ value indicates an increasing

7 trend, while a negative Z- value denotes a decreasing trend. The Mann-Kendall test statistic is given by equation 81.

$$
\sum_{i=1}^{n-1} \sum_{j=i+1}^{n} \operatorname{sign}\left(T_{j}-T_{i}\right) \ldots \ldots \ldots
$$

Where $\mathrm{Tj}$ and $\mathrm{Ti}$ are climate variables in year ' $\mathrm{j}$ ' and ' $\mathrm{i}$ ' respectively given $\mathrm{j}>\mathrm{i}$.

$$
\operatorname{sign}\left(T_{j}-T_{i}\right)=\left\{\begin{array}{l}
-1 \text { if } T_{j}<T_{i} \\
0 \text { if } T_{j}=T_{i} \\
1 \text { if } T_{j}>T_{i}
\end{array}\right.
$$

If the number of observations is greater than 10, Mann-Kendall statistic assumed to follow a normal distribution with variance equal to

$$
\sigma^{2}=\frac{n(n-1)(2 n+5)}{18} \ldots \ldots \ldots
$$

We can use $\mathrm{Z}$ test to test the significance of the trend. The standard $\mathrm{Z}$ statistic, $\mathrm{Zs}$ is

$$
Z_{s}=\left\{\begin{array}{l}
\frac{S-1}{\sigma} \text { if } S>0 \\
0 \text { if } S=0 \quad \ldots \ldots \ldots(4) \\
\frac{S+1}{\sigma} \text { if } S<0
\end{array}\right.
$$

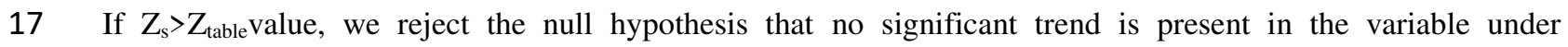
consideration.

The magnitude of underlying trend is quantified using Sen's slope estimator, wherein the slope is computed as the change in measurement per unit change in time.

$$
\mathrm{Q}=\frac{\mathrm{X}_{\mathrm{j}}-\mathrm{X}_{\mathrm{k}}}{\mathrm{j}-\mathrm{k}}, \mathrm{k} \neq \mathrm{j}
$$

For a time series $\mathrm{X}$ within observations, there are possible $\mathrm{N}=\mathrm{n}(\mathrm{n}-1) / 2$ values of $\mathrm{Q}$ that can be calculated. According to Sen's method, the overall estimator of slope is the median of Q's N values. The overall slope estimator, $Q^{*}$ is thus:

$$
\mathrm{Q}^{*}=\left\{\begin{array}{c}
\mathrm{Q}_{\frac{\mathrm{N}+1}{2}}, \mathrm{~N} \text { is odd } \\
\frac{Q_{\left(\frac{N}{2}\right)}+Q_{\left[\frac{N+2}{2}\right]}}{2}, \mathrm{~N} \text { is even }
\end{array}\right.
$$


The $\mathrm{Q}^{*}$ sign indicates the trend in data, while its value indicates the steepness of the trend.

2

3

4 5

6

7

2.3.2. Methods for estimating climate change impact on crop production

Several methods have been employed in literature to estimate the economic impact of climate change on agriculture, which can be broadly classified into following approaches viz., production function approach, Ricardian analysis, and panel data approach. The production function approach is often based on experimental data and provides an excellent structural form. But it fails to incorporate farmers' adaptation to minimize harmful effects due to climate change, thereby results in biased estimates of climatic parameters. In Ricardian analysis, farmland productivity is measured in terms of land rents (Lippert 2009) or land value (Feres et al. 2008) or net farm revenues (Mendelsohn and Dinar 2003; Mendelsohn 2009). Farmland productivity is regressed against long-run climate normals and a set of exogenous variables to estimate the potential economic impact. As Ricardian analysis holds basic assumptions of perfect competition and profit maximizing farmers, it accounts for both direct impacts on crop yields as well as indirect impact in terms of substitution of inputs, the introduction of different activities, and other potential adaptations to reduce the ill-effects due to climate change (Mendelsohn et al. 1994). However, the hedonic approach may confound the impact of climate variables with other unmeasured characteristics like soil quality that may have a bearing on land values or net revenues resulting in biased estimates of climate variables (Deschenes and Greenstone 2007). Panel data regression models control for omitted variable bias by using spatial and time fixed effects (Blanc and Schelkner 2017) and it gives estimates which are robust and consistent over time (Choudhary and Sirohi 2020). Hence, we use this method to estimate the impact of temperature on wheat yield. The empirical specification has been provided in the next section.

\subsubsection{Model specification}

We assumed wheat yield as a function of climate factors, inputs, production technology and land quality. Principal inputs such as human labor, irrigation, seed and fertilizers were included in the model, wherein the first three inputs were considered in real monetary terms (Rupees per hectare), while fertilizer was included in quantity terms (kg per hectare). Wheat cultivation in IGP witnessed progressive mechanization over the years by replacing draft power and human labor. The relative share of bullock labor in total power expenses has declined drastically over the years, with a proportionate increase in machine labor share. Taking this substitution into account, the expenditure on machine labor and bullock labor were clubbed together under the head, 'power expenses'. Expenses on other minor inputs like expenditure on insecticides and pesticides, expenditure on manure, and other miscellaneous expenditures were clubbed together because they accounted for a small proportion of total costs but varied substantially over the years. Regional dummies were used to account for time persistent region-specific variations in natural endowments and socio-economic factors. The impact of technological change and increase in yield potential of varieties was captured using a time trend variable. The proportion of wheat in the total cultivated area (referred to as regional specialization hereon) is used as a proxy to capture the effect of variables like land quality, government support programs, etc., which facilitate wheat cultivation in the region but tend to vary over time. 
The wheat yield function is specified as follows,

$$
\ln Y i e l d_{i t}=\left(\alpha_{0}+\alpha_{1} t\right)+\sum_{j=1}^{6} \beta_{j} \ln X_{j i t}+\gamma \ln R_{i t}+w C_{i t}+\sum_{r=2}^{5} \delta_{r} D_{r}+u_{i t}
$$

where Yield $_{i t}$ represents wheat yield for state 'i' at time 't' (where time period t vary from 1980 to 2009), $X_{j i t}$ represents the vector of inputs like human labor, power, seed, irrigation and other inputs, $R_{i t}$ alludes to regional specialization, $C_{i t}$ is vector of climate variables, $D_{r}$ is the vector of regional dummies. Here, $\alpha, \beta, \gamma, w, \delta$ are parameters to be estimated and $u_{i t}$ is the error term. Two models, Model 1 and Model 2 were estimated separately to quantify the impact of crop growing season temperature (GST) and terminal stage temperature (TST) on wheat yield, respectively. By estimating two models, we tried to discern the marginal impact of GST and TST on the productivity of wheat. Yield and input variables were transformed into logarithmic form to reduce excess variations in values, whereas the regional specialization temperature variables were retained as such. Previous studies reported a non-linear relationship between temperature and crop yields (Schelkner and Roberts 2009; Guiteras 2007); hence, both average temperature and its squared term were included in both models. The coefficients of climate variables may be interpreted as the relative change in yield due to a unit change in climatic variables, while the coefficient of input vectors may be construed as elasticity.

The marginal effects of a unit increase in temperature on wheat yields at the mean yield level were computed using Equation 8.

$$
\frac{\partial Y_{i t}}{\partial T_{i t}}=\beta_{1}+2 * \beta_{2} * T
$$

where $\beta_{1}$ and $\beta_{2}$ are the coefficients of temperature and squared temperature terms, and $\mathrm{T}$ is the mean value of temperature.

\section{Results and Discussion}

Table 1: Trend in growing season temperature and terminal stage temperature

\begin{tabular}{lcccccc}
\hline & \multicolumn{2}{c}{ Growing Season Temperature (GST) } & \multicolumn{3}{c}{ Terminal Stage Temperature (TST) } \\
\cline { 2 - 6 } State & $\begin{array}{c}\text { MK } \\
\text { Statistic }\end{array}$ & Z-Statistic & $\begin{array}{c}\text { Sen's Slope } \\
\text { Estimator }\end{array}$ & $\begin{array}{c}\text { MK } \\
\text { Statistic }\end{array}$ & Z-Statistic & $\begin{array}{c}\text { Sen's Slope } \\
\text { Estimator }\end{array}$ \\
\hline Bihar & 92 & $1.80^{*}$ & 0.021 & 124 & $2.43^{* * *}$ & 0.048 \\
Haryana & 186 & $3.65^{* * *}$ & 0.051 & 164 & $3.22^{* * *}$ & 0.087 \\
Punjab & 190 & $3.73^{* * *}$ & 0.048 & 174 & $3.42^{* * *}$ & 0.084 \\
Rajasthan & 196 & $3.85^{* * *}$ & 0.053 & 162 & $3.18^{* * *}$ & 0.076 \\
UP & 148 & $2.90^{* * *}$ & 0.036 & 160 & $3.14 * * *$ & 0.069
\end{tabular}


Before discussing the impact of various factors on wheat yield, it is appropriate to understand the trend and

2 magnitude of increase in both GST and TST. Mann-Kendall (MK) test was used to test the significance of trends

3 in GST and TST. The magnitude of trend was computed using Sen's slope estimator. The results are presented

4 in Table 1. As evident from the table, GST has increased significantly in all states. The annual rate of increment

5 in GST was found to be highest for Rajasthan $\left(0.053^{\circ} \mathrm{C}\right)$ followed by Haryana $\left(0.051^{\circ} \mathrm{C}\right)$ and Punjab $\left(0.048^{\circ} \mathrm{C}\right)$,

6 indicating that the North-Western regions of IGP are likely to be more vulnerable to heat stress. A significant

7 increasing trend was observed in TST in all selected states, while an annual increment in TST was found nearly

8 twice as that of GST.

$9 \quad$ Table 2: Descriptive statistics

\begin{tabular}{|c|c|c|c|c|c|}
\hline Variable & Description & Unit & Mean & SD & $\mathbf{C V}$ \\
\hline Yield & Yield of the crop & $\mathrm{kg} / \mathrm{ha}$ & 2818 & 904 & 32.08 \\
\hline Human Labour & Expenditure for human labour & $\mathrm{Rs} / \mathrm{ha}$ & 3469 & 785 & 22.63 \\
\hline Power & $\begin{array}{l}\text { Expenditure for both machine } \\
\text { labour and bullock labour }\end{array}$ & $\mathrm{Rs} / \mathrm{ha}$ & 2885 & 718 & 24.89 \\
\hline Seed & Seed expenses & $\mathrm{Rs} / \mathrm{ha}$ & 1125 & 231 & 20.53 \\
\hline Irrigation & Irrigation expenses & Rs/ha & 1333 & 590 & 44.26 \\
\hline Other Inputs & $\begin{array}{l}\text { Expenditure for other inputs such } \\
\text { as pesticides, manure and other } \\
\text { purposes }\end{array}$ & Rs/ha & 2317 & 875 & 37.76 \\
\hline Fertilizer & Quantity of fertilizer used per ha & $\mathrm{kg} / \mathrm{ha}$ & 136 & 55 & 40.44 \\
\hline $\begin{array}{l}\text { Regional } \\
\text { Specialization }\end{array}$ & $\begin{array}{l}\text { Area under wheat in a state in } \\
\text { proportion to total wheat cultivated } \\
\text { area in India }\end{array}$ & $\%$ & 46.3 & 23 & 49.68 \\
\hline $\begin{array}{l}\text { Growing Season } \\
\text { Temperature }\end{array}$ & $\begin{array}{l}\text { Mean temperature during crop } \\
\text { growing season }\end{array}$ & ${ }^{0} \mathrm{C}$ & 18.2 & 1.7 & 9.34 \\
\hline $\begin{array}{l}\text { Terminal stage } \\
\text { Temperature }\end{array}$ & $\begin{array}{l}\text { Mean temperature during terminal } \\
\text { stage of crop (March to April) }\end{array}$ & ${ }^{0} \mathrm{C}$ & 20.0 & 2.1 & 10.50 \\
\hline
\end{tabular}

SD-Standard deviation, CV-Coefficient of variation

11 Table 2 provides descriptive statistics of variables included in the estimation of the yield response function. It 12 can be observed that both yield and input usage display a considerable degree of variation. The stationarity of dependent and independent variables was checked using Im-Pesaran-Shin test (Im et al. 2003). The null

14 hypothesis of all panels being unit roots was rejected at a 1 percent level of significance, indicating that the variables in the models were stationary (Table A.1 in Appendix). The ordinary least squares (OLS) technique was used to estimate coefficients, and the residuals of the model were subjected to a series of diagnostic tests. The Modified- Wald test for heteroskedasticity (Greene 2000) indicated that the residuals obtained from models estimated by OLS procedure violated the assumption of constant variance. Wooldridge test of autocorrelation in 
1 panel data (Wooldridge 2002; Drukker 2003) revealed that OLS estimation procedure had autocorrelation 2 problems. The coefficients obtained from the fixed effects model in cross-sectional dependence are consistent.

3 However, they are not efficient and have biased standard errors. The presence of cross-sectional dependence

4 was checked using Pesaran's test (Pesaran 2004), which confirmed cross-sectional dependence in data. Results

5 of auto-correlation, heteroskedasticity, and cross-sectional dependence tests are provided in Table A.2 in

6 Appendix.

7 Table 3: Impact of Growing Season Temperature (GST) on wheat yield

\begin{tabular}{|c|c|c|c|c|c|c|}
\hline \multirow[b]{2}{*}{ Variables } & \multicolumn{3}{|c|}{ Fixed effects (within) } & \multicolumn{3}{|l|}{ FGLS $^{\$}$} \\
\hline & Coefficients & $\begin{array}{l}\text { Standard } \\
\text { Error }\end{array}$ & $\begin{array}{l}p- \\
\text { value }\end{array}$ & Coefficients & $\begin{array}{l}\text { Standard } \\
\text { Error }\end{array}$ & p-value \\
\hline Ln_Human Labor & 0.13 & 0.04 & 0.01 & 0.14 & 0.03 & 0.01 \\
\hline Ln_Power & -0.14 & 0.04 & 0.01 & -0.12 & 0.03 & 0.01 \\
\hline Ln_Seed & -0.08 & 0.04 & 0.03 & -0.07 & 0.03 & 0.02 \\
\hline Ln_Irrigation & 0.01 & 0.02 & 0.61 & 0.00 & 0.02 & 0.54 \\
\hline Ln_Fertilizer & 0.24 & 0.05 & 0.01 & 0.18 & 0.05 & 0.01 \\
\hline Ln_Other Inputs & -0.09 & 0.05 & 0.09 & -0.03 & 0.04 & 0.54 \\
\hline GST & 0.35 & 0.12 & 0.01 & 0.25 & 0.10 & 0.02 \\
\hline Squared GST & -0.01 & 0.00 & 0.01 & -0.01 & 0.00 & 0.01 \\
\hline Regional Specialization & -0.38 & 0.09 & 0.01 & -0.23 & 0.09 & 0.01 \\
\hline Time & 0.01 & 0.00 & 0.01 & 0.01 & 0.00 & 0.01 \\
\hline Haryana & 0.75 & 0.06 & 0.01 & 0.67 & 0.07 & 0.01 \\
\hline Punjab & 0.96 & 0.09 & 0.01 & 0.82 & 0.10 & 0.01 \\
\hline Rajasthan & 0.06 & 0.08 & 0.49 & 0.06 & 0.08 & 0.45 \\
\hline Uttar Pradesh & 0.39 & 0.05 & 0.01 & 0.32 & 0.05 & 0.01 \\
\hline Intercept & 5.82 & 1.21 & 0.01 & 5.80 & 1.01 & 0.01 \\
\hline Within variation & 0.83 & & & Wald Chi-Squ & Statistic & 3058.3 \\
\hline Between variation & 0.29 & & & No. of observ & & 140 \\
\hline No. of observations & 140 & & & & & \\
\hline
\end{tabular}

${ }^{\$}$ Feasible generalized least squares

9 The presence of autocorrelation, heteroskedasticity, and cross-sectional dependence in the data indicated that the

10 estimated coefficients might not be efficient and were likely to have inflated standard errors. Feasible

11 Generalized Least Square (FGLS) estimation procedure was used in the past to generate standard errors that are

12 asymptotically consistent and efficient (Kmenta 1986) in place of OLS estimators that are inefficient. Another 
potential problem is omitted variable bias as factors like diseases and pests (influenced by temperature) that might affect wheat yield have not been included in the model. The Ramsey regression specification error test

3 (Ramsey, 1969) was used to test the specification bias, and the assumption was satisfied by two models

$4 \quad$ ( $>>10.13 \%$ and $\mathrm{P}>17.30 \%$ for model1 and model 2, respectively). The estimated coefficients of Model 1 are presented in Table 3 .

All independent variables except irrigation were found to be statistically significant in the OLS estimates for Model 1. The FGLS estimates differ slightly from the OLS estimates with slight improvements. The use of fertilizer contributed positively to yield growth, as expected. Human labour also was found to be positively correlated with wheat yield. Similar findings were reported in some previous studies also, and the reason is that progressive mechanization increased the productivity of human labour in Indo-Gangetic plains (Sekhar and Pal, 2012). Marginal returns to seeds were negative, pointing towards its over application. As shown in figure 4, lowess plot between seed expenditure and yield per hectare also indicate a negative relationship in three states out of five states considered for the study. Previously, it has been reported that supra-optimal density of planting in wheat and paddy results in increased crop competition due to nutrient stress (Jha et al. 2018). Even though the optimal seed rate is determined by various factors such as soil fertility, irrigation, climate, etc., the recommended seed rate for wheat in India is $100 \mathrm{~kg} / \mathrm{ha}$ under ideal planting conditions (GoI 2010). But average seed rate in the five selected states was $128.32 \mathrm{~kg} / \mathrm{ha}$ in 2010 as calculated using data from the Directorate of Economics and Statistics, Government of India indicating an increase of nearly 28 percent over the optimal plant population. This could be the plausible reason for negative marginal returns.

The irrigation variable's coefficient was positive but not statistically significant, which is not in line with the findings of previous studies. Zaveri and Lobell (2019), reported that wheat yield in India during 2000s was 13 percent higher than it would have been without irrigation, and it is to be noted that irrigation development in wheat cultivation has contributed significantly to reduce impact of heat sensitivity on yield, albeit the fact that this effect is reducing in recent years. In our study, the data used for the analysis is of more recent years. In major wheat-growing areas of IGP, the wheat crop is almost fully irrigated for most of the years considered, which could render the variable statistically insignificant. The data used for representing irrigation in the paper is the actual expenditure incurred for irrigation, used in real terms. Given the high level of subsidy for groundwater-based irrigation development and the flat rate of surface irrigation charges, the irrigation expenditure also has not shown much variation over the years. Additionally, we have used 'fertilizer' in our analysis, unlike Zaveri and Lobell (2019), which assumes full potential only with irrigation. In the presence of lack of variability in irrigation expenditure over the years in all the states considered and significant variations in the fertilizer application, the fertilizer coefficient turned statistically significant.

The time trend was positive and significant, indicating that technological change positively contributed to yield growth during the study period. Contrary to our expectation, regional specialization was found to be negatively correlated with wheat yield. This may be attributed to the conventional practice of a rice-wheat cropping system in the IGP that deteriorates soil fertility and land quality. This adversely affects productivity and sustainability (Ladha et al. 2007; Singh and Singh 2012). The marginal returns to mechanization were found to be negative. Singh et al. 2007 highlighted the need to optimize mechanization in wheat production. The study indicates that operations in major wheat-producing states like Punjab and Haryana tend to be over-mechanized. Besides, the 
coefficient of other inputs was also negative possibly because the major share of these inputs comprised the

2 expenditure on pesticides. Increased pesticide application is associated with a corresponding increase in disease

3 infestation or pest attacks. Yields are typically lower in years with higher pest or disease incidence, potentially

4 explaining negative correlation between yields and pesticide application. Finally, coefficients of both normal

5 and squared terms of GST were found to be significant. The coefficient of average GST was positive while that

6 of the squared term was negative, justifying our hypothesis of a non-linear relationship (quadratic) between

7 wheat yield and GST. The expected marginal effect of a unit increase in average growing season temperature

8 was worked out, and it indicates that a $1^{\circ} \mathrm{C}$ rise in GST reduces the yield by 2.03 percent.

$9 \quad$ Table 4: Impact of Terminal Stage Temperature (TST) on wheat yield

\begin{tabular}{|c|c|c|c|c|c|c|}
\hline \multirow[b]{2}{*}{ Variables } & \multicolumn{3}{|c|}{ Fixed effects (within) } & \multicolumn{3}{|l|}{ FGLS } \\
\hline & Coefficients & $\begin{array}{l}\text { Standard } \\
\text { Error }\end{array}$ & p-value & Coefficients & $\begin{array}{l}\text { Standard } \\
\text { Error }\end{array}$ & p-value \\
\hline Ln_Human Labour & 0.12 & 0.04 & 0.01 & 0.13 & 0.03 & 0.01 \\
\hline Ln_Power & -0.13 & 0.04 & 0.01 & -0.12 & 0.03 & 0.01 \\
\hline Ln_Seed & -0.08 & 0.04 & 0.04 & -0.07 & 0.03 & 0.02 \\
\hline Ln_Other Inputs & -0.09 & 0.05 & 0.08 & -0.04 & 0.04 & 0.41 \\
\hline Ln_Irrigation & 0.01 & 0.02 & 0.58 & 0.01 & 0.02 & 0.80 \\
\hline Ln_Fertilizer & 0.23 & 0.05 & 0.01 & 0.18 & 0.05 & 0.01 \\
\hline TST & 0.16 & 0.06 & 0.01 & 0.09 & 0.05 & 0.09 \\
\hline Squared TST & -0.01 & 0.01 & 0.01 & -0.01 & 0.01 & 0.04 \\
\hline Regional Specialization & -0.37 & 0.09 & 0.01 & -0.23 & 0.09 & 0.01 \\
\hline Time & 0.02 & 0.00 & 0.01 & 0.02 & 0.00 & 0.01 \\
\hline Haryana & 0.98 & 0.05 & 0.01 & 0.67 & 0.06 & 0.01 \\
\hline Punjab & 0.94 & 0.06 & 0.01 & 0.79 & 0.09 & 0.01 \\
\hline Rajasthan & 0.18 & 0.15 & 0.01 & 0.07 & 0.08 & 0.39 \\
\hline Uttar Pradesh & 0.54 & 0.09 & 0.01 & 0.33 & 0.05 & 0.01 \\
\hline Intercept & 8.32 & 0.82 & 0.01 & 7.16 & 0.69 & 0.01 \\
\hline Within variation & 0.83 & & & Wald Chi-Sq & Statistic & 2805.6 \\
\hline Between Variation & 0.26 & & & No. of Obser & ns & 140 \\
\hline No. of observations & 140 & & & & & \\
\hline
\end{tabular}


The result of the estimation of Model 2 is presented in Table 4. Despite slight variations in the values of the

2

3 coefficients, the signs are identical to Model 1 . The marginal impact of $1^{\circ} \mathrm{C}$ increase in TST at mean yield levels resulted in a 2.26 percent reduction in yield. The results imply that heat stress during terminal stages of crop growth is more detrimental to wheat productivity in the IGP. The results align with the previously reported findings (Nagarajan 2005; Spiertz 2006; Singh et al. 2011).Since the primary focus is to discern the contribution of temperature on wheat yields, it is convenient to treat the impact of non-climate factors as residuals (You et al. 2009). The climate yield function (Yield ${ }^{\text {climate }}$ ) was estimated by subtracting the contribution of non-climate factors (You et al. 2009). The Yield ${ }^{\text {climate }}$ is calculated using the following equation:

$$
\text { lnYield }^{\text {climate }}=\operatorname{lnYield}_{i t}-\left(\alpha_{0}+\alpha_{1} t\right)-\sum_{j=1}^{6} \beta_{j} \ln X_{j i t}-\gamma \ln R_{i t}-\sum_{r=2}^{5} \delta_{r} D_{r} \ldots \ldots \ldots(9)
$$

The values of the natural logarithm of Yield ${ }^{\text {climate }}$ were plotted against the GST (Figure 2) and TST (Figure 3). The downward sloping trend lines indicate the negative impact of temperature on wheat yields.

(Insert Fig 3 here)

The optimum temperatures for wheat growth are $\sim 22^{\circ} \mathrm{C}$ for vegetative development and $21^{\circ} \mathrm{C}$ for reproductive development, while $\sim 35.4^{\circ} \mathrm{C}$ is the maximum limit for grain filling (Porter and Gawith 1999). Wheat crop is highly susceptible to heat stress, particularly during the grain filling stage (Farooq et al. 2011). Due to proximity to the equator and popular cropping systems followed in India that involves late sowing of wheat, wheat crop faces exposure to terminal heat stress, which means average daily temperatures above $17.58^{\circ} \mathrm{C}$ during the growing period (Joshi et al. 2007). High temperature reduces the phenological duration, source-sink metabolism, grain number, grain weight, grain yield, and grain quality (Asseng et al. 2011). An increase in temperature has been correlated with the decline in wheat yield in North-western India, as the rise in temperature in the month of March is particularly detrimental to crop yield (Mukherjee et al. 2019). An increase in growing season temperature above the optimal range $\left(17-26^{\circ} \mathrm{C}\right)$ by $1{ }^{\circ} \mathrm{C}$ reduces grain yields by $4 \%$ in wheat (Acevedo and Nachit 1990). Our study results indicated that the potential impact of GST rise is likely to be lower since the study accounts for a wide range of on-farm adaptations to climate change using spatial fixed effects and variation in input use over time. This could explain the disparity in estimated impacts on wheat yield across regions over time. The findings of previous studies on impact of climate change on wheat yield in India and South Asia have been tabulated in Table 5.

Simulation models have been widely used to predict the potential impact of climate change on wheat yield in India. A study conducted by Kumar et al. (2014) has predicted that wheat yield would reduce by 6 percent for timely sown wheat by 2050 . Surface temperatures are predicted to increase by $1.5-3^{0} \mathrm{C}$ by 2050 (Mani et al. 2018). Therefore the predicted impact in the form of reduction in wheat yield by 2050 using our estimates would be in a range of 3-6 percent, which concurs with simulation model results for the same period. However, some 

in temperature above $3{ }^{\circ} \mathrm{C}$ would cancel out potential gains (Lal et al. 1998).

Table 5: Comparison with previous studies

\begin{tabular}{|c|c|c|}
\hline Study & Region & Predicted Impact \\
\hline Kumar et al. 2014 & $\begin{array}{l}\text { Indo- } \quad \text { Gangetic } \\
\text { Plains }\end{array}$ & Predicted yield reduction by 2050 was $6-23 \%$ and $15-25 \%$ by 2080 \\
\hline $\begin{array}{l}\text { Attri and Rathore, } \\
2003\end{array}$ & North India & $\begin{array}{l}\text { Reduction in yield by } 8.2-14.3 \% \text { and } 0.3-0.9 \% \text { in rainfed and irrigated } \\
\text { conditions respectively under A1 scenario. }\end{array}$ \\
\hline Lal et al.1998 & western & $\begin{array}{l}\text { The combined effect of thermal stress and increase in } \mathrm{CO}_{2} \text { concentration } \\
\text { amounted to } 21 \% \text { increase in wheat yields. }\end{array}$ \\
\hline Birthal et al. 2014 & India & $\begin{array}{l}\text { Wheat yield was predicted to decrease by } 0.5-8.5 \% \text { by } 2035 \text { and } 3.5- \\
15.4 \% \text { by } 2065 \text {. }\end{array}$ \\
\hline Lobell et al. 2012 & $\begin{array}{l}\text { Indo-Gangetic } \\
\text { Plains }\end{array}$ & Reduction in yields by $20 \%$ for an increase in temperature by $2^{0} \mathrm{C}$. \\
\hline You et al. 2009 & China & Wheat yield was predicted to decrease by $3-10 \%$ due to climate change. \\
\hline
\end{tabular}

4

Several studies have reiterated the importance of accounting for non-climate factors while estimating the potential impact on crop yields directly (You et al. 2009; Zhai et al. 2017). However, direct estimation studies in the Indo-Gangetic plains have failed to account for a wide range of non-climate factors while estimating potential impact of climate change (Birthal et al. 2014). The estimated impact of climate change was found higher than our estimates, although the lower bound values are similar. Accounting for non-climate factors like variations in input use provides realistic forecast, especially in regions that have experienced a spurt in input usage (You et al. 2009); also it helps to control for confounding errors and provide more optimistic estimates of potential impact.

\section{Economic implications}

An attempt is made to estimate the economic impact of one-degree rise in GST and TST on wheat yield in five selected states by multiplying marginal effects of GST and TST with mean annual production during the entire study period. The results indicated that a one-unit rise in GST and TST leads to an annual loss of 1.04 million tonnes and 1.12 million tonnes of wheat, respectively, for the five states together. Some of the recent studies reported that climate change has slowed down agricultural total factor productivity (TFP) growth (Zhong et al. 2019; Ortiz-Bobea et al. 2021). TFP growth is the residual of the output growth not accounted for by the input growths, determined mainly by research and development. The annual total factor productivity (TFP) growth of wheat in India for 1975-2005 is about 1.92 percent (Chand et al. 2011). At the state level, it is about 1.3 percent in Punjab, 1.7 percent in Haryana, 1.8 percent in Rajasthan, and 1.6 percent in Uttar Pradesh (Mittal and Kumar, 2005). The share of TFP growth in output growth of wheat is about 58.9 percent at the national level (Chand et 
al. 2011). We calculated the trend growth in wheat production in the five states following an exponential growth model and about 2.43 percent per year. This turns out that the contribution of TFP in the output growth is about 1.43 percent. This shows that the TFP growth in India's wheat production has occurred against the loss caused by temperature rise, either as GST or TST. We compare the impact of temperature rise against the TFP growth in wheat production in India. The annual production increment of wheat in the five states due to TFP growth turns out to be to the tune of 0.98 million tonnes at mean, whereas that of a one-unit increase in GST and TST could turn out to be to the tune of 1.04 and 1.12 million tonnes, respectively.

\section{Limitations of the study}

This study has not considered the positive effects of elevated $\mathrm{CO}_{2}$ concentration on wheat yield. The estimates obtained from the study may be regarded as upper-bound estimates. Besides, the study estimated the potential impact on timely sown wheat. However, delayed planting exposes the wheat crop to severe heat stress that could reduce wheat yield exponentially (Lobell et al. 2012; Singh et al. 2011). Several factors like the delayed establishment of rice nurseries and hence delayed harvesting in the Upper Gangetic Plains of India have increased incidence of delayed planting of wheat (Dwivedi et al. 2017; Kumar et al. 2019), which may further adversely affect wheat yield. In the event of perceived negative impacts on wheat yield, farmers are expected to adapt by using early maturing varieties or other agronomic measures. However, the present study tried to provide estimates after accounting for contribution of non-climatic factors, which largely represent farmers' adaptation behaviors and spatial effects.

\section{Conclusions}

This study tried to segregate the impact due to climatic and non-climatic factors on wheat yield. We also analyzed two separate models, including growing season temperature (GST) and terminal stage temperature (TST) to understand the extent of impact on yield due to rise in temperature at various stages of crop growth. During the study period, there was a significant increase in GST and TST in major wheat-producing regions of the IGP, whereas the latter's growth rate was almost twice the former. Annual increment in GST ranges from $0.021^{\circ} \mathrm{C}$ to $0.053^{\circ} \mathrm{C}$ while it ranges from $0.048^{\circ} \mathrm{C}$ to $0.087^{\circ} \mathrm{C}$ in case of TST. The relationship between wheat yield and temperature (both GST and TST) was found to be negative and non-linear. The adverse effect of rising temperature was more prominent in the terminal stages of wheat growth. As per our study, an increase in GST by $1^{\circ} \mathrm{C}$ reduces wheat productivity by 2.03 percent, while a similar increase during the terminal stage reduces yield by 2.26 percent. It contrasts well with the TFP growth in output growth of wheat, at 1.43 percent per year. The TFP growth contributes to about an increment of 0.98 million tonnes of wheat annually in the five IGP states considered. But one unit increase in GST and TST could impact a production loss to the tune of 1.04 and 1.12 million tonnes, respectively. Therefore, the temperature rise depresses the TFP growth and, therefore, the output growth in wheat in the selected IGP states. Thus, the undesirable effects of climate change on wheat yields could undermine the efforts to ensure the burgeoning population's food security. Therefore, concerted efforts need to be made for developing adaptation strategies to moderate the impact of rising temperature. 
3 Conflicts of Interest / Competing Interests :

4 The authors have no relevant financial or non-financial interests to disclose.

\section{Funding Statement:}

$6 \quad$ No funding was received for conducting this study.

\section{Authors contribution:}

8 All authors contributed significantly for conducting this study and preparing this manscript as follows; Study 9 Conception : Dr. Girish K. Jha; Design- Dr. Girish K. Jha, Mr. Philip Kuriachen, Dr. Asha Devi, S.S; Data 10 Collection \& Analysis- Mr. Philip Kuriachen, Dr. Asha Devi, S.S; Original draft preparation - Mr. Philip 11 Kuriachen, Dr. Asha Devi, S.S; Review and editing- Dr.Anu Susan Sam, Dr. Suresh Kumar, Dr. Jyothi Kumari, Dr.A. Suresh; Supervision- Dr. Girish K. Jha. All authors read and approved the final manuscript.

Availability of data and material:. author on reasonable request.

Code Availability: The analysis for this study was carried out using licenced STATA/SE 15 software. We have undertaken only menu driven procedures and not used any custom codes.

Ethics approval: Not Applicable 
Acevedo E, Nachit M (1990) Effects of heat stress on wheat and possible selection tools for use in breeding for tolerance. In 3: International conference on wheat for the non-traditional warm areas. Foz do Iguacu (Brazil). 29 Jul-3 Aug 1990.

Aggarwal PK (2008) Global climate change and Indian agriculture: impacts, adaptation and mitigation. Indian J. Agric. Sci 78: 911-919.

Aggarwal PK, Naresh Kumar S, Pathak H (2010) Impacts of climate change on growth and yield of rice and wheat in the upper ganga basin. http://www.wwfindia.org.

Ahmed I, ur Rahman MH, Ahmed S, Hussain J, Ullah A, Judge J (2018) Assessing the impact of climate variability on maize using simulation modeling under semi-arid environment of Punjab, Pakistan. Environ. Sci. Pollut. Res. 25 (28), 28413-28430. https://doi.org/10.1007/s11356-018-2884-3.

Amjath-Babu T S, Krupnik T J, Aravindakshan S, Arshad M, Kaechele H (2016) Climate change and indicators of probable shifts in the consumption portfolios of dryland farmers in sub-Saharan Africa: implications for policy. Ecol. Indic. 67, 830-838.

Asseng S, Ewert F, Martre P, Rötter RP, Lobell DB, Cammarano D, Reynolds M P (2015) Rising temperatures reduce global wheat production. Nat.Clim.Chang 5(2): 143. doi: 10.1038/nclimate2470.

Asseng S, Foster IAN, Turner NC (2011) The impact of temperature variability on wheat yields. Glob.Chang. Biol 172: 997-1012.

Attri SD, Rathore LS (2003) Simulation of impact of projected climate change on wheat in India. Int. J. Climato 236: 693-705.

Bhuyan B, Sahoo B K, Suar D (2020) Nutritional status, poverty, and relative deprivation among socioeconomic and gender groups in India: Is the growth inclusive? World Development Perspectives, 18: 100180.

Birthal PS, Khan TM, Negi DS, Agarwal S (2014) Impact of climate change on yields of major food crops in India: Implications for food security. Agric. Econ. Res. Rev 27(2):145-155.

Blanc E, Schlenker W (2017) The use of panel models in assessments of climate impacts on agriculture. Rev. Environ. Econ. Policy 112: 258-279.

Burt T, Boardman J, Foster I, Howden N (2016) More rain, less soil: long-term changes in rainfall intensity with climate change. Earth Surf. Process. Landf 41(4): 563-566.

Chand R, Kumar P, Kumar S (2011) Total Factor Productivity and Contribution of Research Investment to Agricultural Growth in India, Policy Paper 25, ICAR-National Institute of Agricultural Economics and Policy Research, New Delhi.

Choudhary B B, Sirohi S (2020) Modelling climate sensitivity of agriculture in Trans- and Upper Gangetic Plains of India. Theor Appl Climatol 142:381-391. https://doi.org/10.1007/s00704-020-03297-y

Deryng D, Conway D, Ramankutty N, Price J and Warren R (2014) Global crop yield response to extreme heat stress under multiple climate change futures, Environ. Res. Lett 9, 034011. https://doi.org/10.1088/17489326/9/3/034011

Deschenes O, Greenstone M (2007) The economic impacts of climate change: evidence from agricultural output and random fluctuations in weather. Am. Econ. Rev 971:354-385.

Dhamija V, Shukla R, Gornott C, Joshi P K (2020) Consistency in vulnerability assessments of wheat to climate change-A district-level analysis in India. Sustainability (Switzerland), 12(19). https://doi.org/10.3390/su12198256

Drukker D M (2003) Testing for serial correlation in linear panel-data models. SJ.32:168-177. 
Dwivedi SK, Basu S, Kumar S, Kumar G, Prakash V, Kumar S, Arora A (2017) Heat stress induced impairment of starch mobilisation regulates pollen viability and grain yield in wheat: Study in Eastern Indo-Gangetic Plains. Field Crops Res 206: 106-114. https://doi.org/10.1016/j.fcr.2017.03.006

Fant C, Schlosser CA, Gao X, Strzepek K, Reilly J (2016) Projections of water stress based on an ensemble of socioeconomic growth and climate change scenarios: a case study in Asia. PLoS One, 11(3), e0150633.

Farooq M, Bramley H, Palta JA, Siddique KH (2011) Heat stress in wheat during reproductive and grain-filling phases. Crit.Rev.Plant.Sci 306:491-507.

Feres JG, Reis EJ, Speranza JS (2008) Assessing the Impact of Climate Change on the Brazilian Agricultural Sector. $46^{\text {th }}$ Congress, July 20-23, 2008, Rio Branco, Acre, Brazil 108136, Sociedade Brasileira de Economia, Administracao e Sociologia Rural (SOBER).

Gornall J, Betts R, Burke E, Clark R, Camp J, Willett K, Wiltshire A (2010) Implications of climate change for agricultural productivity in the early twenty-first century. Philosophical Transactions of the Royal Society B: Biological Sciences 365: 2973-2989.

Government of India (GoI) (2010) Agricultural Statistics at a Glance 2010,Directorate of Economics and Statistics, Ministry of Agriculture and Farmers Welfare, Government of India.

Government of India (GoI) (2019) Agricultural Statistics at a Glance 2019, Directorate of Economics and Statistics, Ministry of Agriculture and Farmers Welfare, Government of India.

Government of India. (2020). Economic Survey 2019-2020, Ministry of Finance, Department of Economic Affairs, Economic Division, New Delhi.

Greene W(2000) Econometric Analysis. Upper Saddle River, NJ: Prentice-Hall.

Guiteras R (2007) The Impact of climate change on Indian agriculture. Working paper, Massachusetts Institute of Technology (MIT), USA.

Gupta R, Somanathan E, Dey S (2017) Global warming and local air pollution have reduced wheat yields in India. Clim. Change 140:593-604. doi: 10.1007/s10584-016-1878-8.

Holst R, Yu X, Grün C (2013) Climate change, risk and grain yields in China. J. Integr. Agric 127: 1279-1291

Hossain M S, Qian L, Arshad M, Shahid S, Fahad S, Akhter J (2019a) Climate change and crop farming in Bangladesh: an analysis of economic impacts. Int. J. Clim. Change Strategies Manage. 11 (3), 424-440.

Houser T, Hsiang SM, Kopp R, Larsen K, Delgado M (2015) Economic risks of climate change: an american prospectus. Columbia University Press.

Howden SM, Soussana JF, Tubiello FN, Chhetri N, Dunlop M, Meinke H (2007) Adapting agriculture to climate change. Proc. Natl. Acad. Sci 10450: 19691-19696

Im KS, Pesaran MH, Shin Y (2003) Testing for unit roots in heterogeneous panels. Journal of econometrics, 1151: 53-74.

Im ES, Pal JS, Eltahir EA (2017) Deadly heat waves projected in the densely populated agricultural regions of South Asia. Sci. Adv. 3(8): e1603322.

Intergovernmental Panel on Climate Change (IPCC) (2007) Climate Change 2007: Synthesis Report. Contribution of Working Groups I, II and III to the Fourth Assessment Report of the Intergovernmental Panel on Climate Change [Core Writing Team, Pachauri, R.K and Reisinger, A. eds.]. IPCC, Geneva, Switzerland, $104 \mathrm{pp}$

Intergovernmental Panel on Climate Change (IPCC) (2014) The physical science basis.Contribution of working group II to the fourth assessment report of the intergovernmental panel on climate change.Cambridge Univ. Press, Cambridge, UK, and New York.

Jha B, Tripathi A (2017) How susceptible is India's food basket to climate change? Soc. Change. 471: 11-27. 
Jha GK, Palanisamy V, Sen B, Choudhary K, Kumar A (2018) Abridging the yield gap in eastern Indian states: Issues and challenges. International Association of Agricultural Economists, July 28 - August 2, 2018, Vancouver, Canada.

Joshi AK, Mishra B, Chatrath R, Ortiz Ferrara G, Singh RP (2007) Wheat improvement in India: present status, emerging challenges and future prospects. Euphytica 157: 431-446.

Kato E, Ringler C, Yesuf M, Bryan E (2011) Soil and water conservation technologies: a buffer against production risk in the face of climate change? Insights from the Nile basin in Ethiopia. Agr.Econ. 425: 593-604.

Kmenta J (1986) Elements of Econometrics, 2nd Edition, New York: Macmillan.

Kumar S, Sharma DK, Singh DR, Biswas H, Praveen KV, Sharma V (2019) Estimating loss of ecosystem services due to paddy straw burning in North-west India. Int. J. Agr. Sustain. 17(2): 146-157.

Kumar SN, Aggarwal PK, Rani DS, Saxena R, Chauhan N, Jain S (2014) Vulnerability of wheat production to climate change in India. Clim. Res. 593:173-187.

Ladha JK, Pathak H, Gupta RK (2007) Sustainability of the rice-wheat cropping system: issues, constraints, and remedial options. J. Crop Improv. 2: 125-136.

Lal M, Singh KK, Rathore LS, Srinivasan G, Saseendran SA (1998) Vulnerability of rice and wheat yields in NW India to future changes in climate. Agric. For.Meteorol. 892: 101-114.

Lippert C, Krimly T, Aurbacher, J (2009) A Ricardian analysis of the impact of climate change on agriculture in Germany. Clim. Change. 97: 593-610.

Lobell DB, Burke MB (2010) On the use of statistical models to predict crop yield responses to climate change. Agric For Meteorol 150: 1443-1452.

Lobell D B, Schlenker W, Costa-Roberts J (2011) Climate trends and global crop production since 1980. Science. 333(6042): 616-620. https://doi.org/10.1126/science.1204531

Lobell DB, Sibley A, Ortiz-Monasterio JI ( 2012) Extreme heat effects on wheat senescence in India. Nat.Clim. Chang 23: 186.

Mani M, Bandyopadhyay S, Chonabayashi S, Markandya A, Mosier T (2018) South Asia's Hotspots: The Impact of Temperature and Precipitation Changes on Living Standards. In South Asia's Hotspots: The Impact of Temperature and Precipitation Changes on Living Standards. World Bank, Washington, DC. https://doi.org/10.1596/978-1-4648-1155-5

Mahmood N, Arshad M, Kächele H, Ma H, Ullah A, Müller K (2019) Wheat yield response to input and socioeconomic factors under changing climate: Evidence from rainfed environments of Pakistan. Science of the total environment, 688:1275-1285. https://doi.org/https://doi.org/10.1016/j.scitotenv.2019.06.266

Mendelsohn R, Dinar A (2003) Climate, water, and agriculture. Land Econ.79: 328-341.

Mendelsohn R (2009) The impact of climate change on agriculture in developing countries. Journal of Natural Resources Policy Research 1:5-19.

Mendelsohn R, Nordhaus WD, Shaw D (1994) The impact of global warming on agriculture: a Ricardian analysis. Am. Econ. Rev 941: 753-771.

Mittal S, Kumar P (2005) Total factor productivity and sources of growth of wheat in India. In P (Eds.) K Joshi, Suresh Pal, PS Birthal, MCS Bantilan, Impact of Agricultural Research: Post-Green Revolution Evidence from India, ICAR-National Institute of Agricultural Economics and Policy Research, New Delhi.

Ministry of Agriculture and Farmers Welfare(MoA\&FW), GoI (2019)Commodity Profile of Wheat- September 2019. https://agricoop.nic.in/sites/default/files/Wheat\%20Profile\%20September\%202019-converted.pdf Accessed on 01-07-20221 
Mukherjee A, Wang SYS, Promchote P (2019) Examination of the climate factors that reduced wheat yield in northwest India during the 2000s. Water 112: 343.

Nagarajan S (2005) Can India produce enough wheat even by 2020? Curr. Sci 899: 1467-1471.

Narayanan S (2015) Food Security in India: The Imperative and its Challenges. Asia Pac. Policy Stud 2(1): $197-$ 209. doi:10.1002/app5.62

Nelson GC, Valin H, Sands RD, Havlík P, Ahammad H, Deryng D, Kyle P (2014) Climate change effects on agriculture: Economic responses to biophysical shocks. Proc. Natl. Acad. Sci 1119: 3274-3279.

Ochieng J, Kirimi L, Mathenge M (2016) Effects of climate variability and change on agricultural production: The case of small scale farmers in Kenya. NJAS-Wageningen Journal of Life Sciences 77:71-78.

Onoz B, Bayazit M (2003) The power of statistical tests for trend detection.Turkish. J. Eng.Env.Sci 27:247-251.

Ortiz-Bobea A, Ault TR, Carrillo CM, Chambers RG, Lobell DB (2021) Anthropogenic climate change has slowed global agricultural productivity growth. Nat Clim Chang 11, 306-312

Parker L, Bourgoin C, Martinez-Valle A, Läderach P (2019) Vulnerability of the agricultural sector to climate change: The development of a pan-tropical Climate Risk Vulnerability Assessment to inform sub-national decision making. PloS one 143: 3274-3279.

Pattanayak A, Kumar KK (2014) Weather sensitivity of rice yield: evidence from India. Clim Chang Econ 5(04):1450011.

Pesaran MH (2004) General diagnostic tests for cross section dependence in panels.University of Cambridge, Faculty of Economics, Cambridge Working Papers in Economics No. 0435.

Porter JR, Gawith M (1999) Temperature and the growth and development of wheat: a review. Eur J. Agron.10: $23-36$.

Rao BB, Chowdary PS, Sandeep VM, Pramod VP, Rao VUM (2015) Spatial analysis of the sensitivity of wheat yields to temperature in India. Agric. For.Meteorol, 200: 192-202.

Rao VUM, Rao AVMS, Kumar PV, Desai S, Saikia US, Srivsatava NN,Venkateswarlu B, (2011) Agricultural Drought: climate change and rainfedagriculture. In: Lecture Notes of the 5th SERC School, Central Research Institute for Dryland Agriculture, Hyadrabad, India, 324

Richardson KJ, Lewis KH, Krishnamurthy PK, Kent C, Wiltshire AJ, Hanlon HM (2018) Food security outcomes under a changing climate: impacts of mitigation and adaptation on vulnerability to food insecurity. Clim.Change. 1471(2): 327-341.

Schlenker W, Roberts MJ (2009) Nonlinear temperature effects indicate severe damages to US crop yields under climate change. Proc. Natl. Acad. Sci. U.S.A., 106(37):15594-15598.

Schubert SD, Stewart RE, Wang H, Barlow M, Berbery EH, Cai W, Hoerling MP, Kanikicharla KK, Koster RD, Lyon B, Mariotti A, Mechoso CR, Muller OV, Rodriguez-Fonseca B, Seager R, Seneviratne SI, Zhang L, Zhou T (2016). Global meteorological drought: a synthesis of current understanding with a focus on SST drivers of precipitation deficits. J.Clim. 29(11): 3989-4019.

Schiermeier Q (2018) Droughts, heatwaves and floods: How to tell when climate change is to blame. Nature, 560(7717): 20-23.

Sehgal V K,Singh M R,Chaudhary A, Jain N,Pathak H (2013) Vulnerability of Agriculture to Climate Change: District Level Assessment in the Indo-Gangetic Plains. Indian Agricultural Research Institute, New Delhi p 74.

Sekar I, Pal S (2012) Rice and wheat crop productivity in the Indo-Gangetic Plains of India: Changing pattern of growth and future strategies. Indian J. Agric. Econ 67(2): 238-252.

Singh H, Singh AK, Kushwaha HL, Singh A (2007) Energy consumption pattern of wheat production in India. Energy 32(10): 1848-1854. 
Singh B, Singh V (2012) Productivity and fertility of soils in the Indo-Gangetic Plains of South Asia. Arch. Agron. Soil Sci 58:S33-S40.

Singh K, Sharma SN, Sharma Y (2011) Effect of high temperature on yield attributing traits in bread wheat.Bangladesh. J.Agr.Res 363: 415-426.

Spiertz JHJ, Hamer RJ, Xu H, Primo-Martin C, Don C, Van Der Putten PEL (2006) Heat stress in wheat

Triticumaestivum L.: Effects on grain growth and quality traits. Eur. J.Agron 252: 89-95.

Subash N, Mohan HR (2012) Evaluation of the impact of climatic trends and variability in rice-wheat system productivity using Cropping System Model DSSAT over the Indo-Gangetic Plains of India.Agric. For. Meteorol 164: 71-81.

Swaminathan MS, Bhavani RV (2013) Food production \& availability--essential prerequisites for sustainable food security. Indian J Med Res 138(3):383-391.

Tack J, Barkley A, Nalley L L (2015) Effect of warming temperatures on US wheat yields. Proc. Natl Acad. Sci. USA. 112:6931-6936. doi: 10.1073/pnas.1415181112.

Tripathi A, Mishra A K (2017) The Wheat Sector in India: Production, Policies and Food Security BT - The Eurasian Wheat Belt and Food Security: Global and Regional Aspects (S. Gomez y Paloma, S. Mary, S. Langrell, \& P. Ciaian (eds.); pp. 275-296). Springer International Publishing. https://doi.org/10.1007/978-3319-33239-0_17

Vermeulen SJ, Aggarwal PK, Ainslie A, Angelone C, Campbell BM, Challinor AJ, Lau C (2012) Options for support to agriculture and food security under climate change. Environ. Sci. Policy.151: 136-144.

Wheeler T, Von Braun J (2013) Climate change impacts on global food security. Sci. 3416145, 508-513.

Wooldridge JM (2002) Econometric analysis of cross section and panel data. Cambridge, MA: MIT Press.

You L, Rosegrant MW, Wood S, Sun D (2009) Impact of growing season temperature on wheat productivity in China. Agric. For.Meteorol. 1496-7:1009-1014.

Yu Q, Li L, Luo Q, Eamus D, Xu S, Chen C, Nielsen D C (2014) Year patterns of climate impact on wheat yields. Int. J. Climatol. 34 (2), 518-528.

Zacharias M, Kumar N, Singh SD, Swaroopa Rani DN, Aggarwal PK (2014) Assessment of impacts of climate change on rice and wheat in the Indo-Gangetic plains. J.Agrometeorolo 16(1): 9-17.

Zaveri E, Lobell DB (2019) The role of irrigation in changing wheat yields and heat sensitivity in India. Nat Commun10.4144. https://doi.org/10.1038/s41467-019-12183-9

Zhong Z, Hu Y, Jiang L (2019) Impact of climate change on acgricultural total factor productivity based on spatial panel data model: evidence from China.

Zhai S, Song G, Qin Y, Ye X, Lee J (2017) Modeling the impacts of climate change and technical progress on the wheat yield in inland China: An autoregressive distributed lag approach. PloS one, 12(9). 2-20

Zhao C, Liu B, Piao S, Wang X, Lobell D B, Huang Y, Huang M, Yao Y, Bassu S, Ciais P, Durand J L, Elliott J, Ewert F, Janssens I A, Li T, Lin E, Liu Q, Martre P, Müller C, Peng S, Penuelas J, Ruane A C, Wallach D, Wang T, Wu D, Liu Z, Zhu Y, Zhu Z, Asseng S (2017) Temperature increase reduces global yields of major crops in four independent estimates. Proc. Natl. Acad. Sci. U. S. A. 114: 9326-9331. 
2 Table A.1 Im-Pesaran-Shin Panel unit root test for stationarity

\begin{tabular}{|l|l|}
\hline Variable & Z-t-slide-bar Statistic \\
\hline Ln_Yield & $-3.84 * * *$ \\
\hline Ln_Human Labour & $-2.00 * *$ \\
\hline Ln_Power & $-1.72 * *$ \\
\hline Ln_Irrigation & $-2.88 * * *$ \\
\hline Ln_Fertilizer & $-2.69 * * *$ \\
\hline Ln_Seed & $-2.10 * *$ \\
\hline Ln_Other Inputs & $-3.20 * * *$ \\
\hline Ln_Regional Specialization & $-4.73 * * *$ \\
\hline Growing Season Temperature & $-4.30 * * *$ \\
\hline Terminal Stage Temperature & $-4.96 * * *$ \\
\hline$* * * * * *$ indicates significance at 1\%, 5\% and 10\% levels of significance
\end{tabular}

4

5

6 Table A.2 Residual Diagnostics

\begin{tabular}{|l|l|l|l|l|l|l|}
\hline \multirow{2}{*}{ Model } & \multicolumn{2}{|l|}{ Modified Wald Test } & \multicolumn{2}{l|}{ Pesaran's test } & \multicolumn{2}{l|}{ Wooldridge test } \\
\cline { 2 - 7 } & Statistic & p-value & Statistic & p-value & F statistic & p-value \\
\hline Model 1 & 41.65 & 0.01 & 4.27 & 0.01 & 10.20 & 0.03 \\
\hline Model 2 & 36.32 & 0.01 & 3.49 & 0.01 & 11.33 & 0.03 \\
\hline
\end{tabular}

7 1. Modified Wald test for group-wise heteroskedasticity, $\mathrm{H}_{0}$ : Error terms are homoskedastic

8 2. Pesaran's test for cross-sectional dependence in panel data, $\mathrm{H}_{0}$ : Error terms are not auto-correlated

9 3. Wooldridge test for autocorrelation in panel data, H0: There is no cross-sectional dependence 


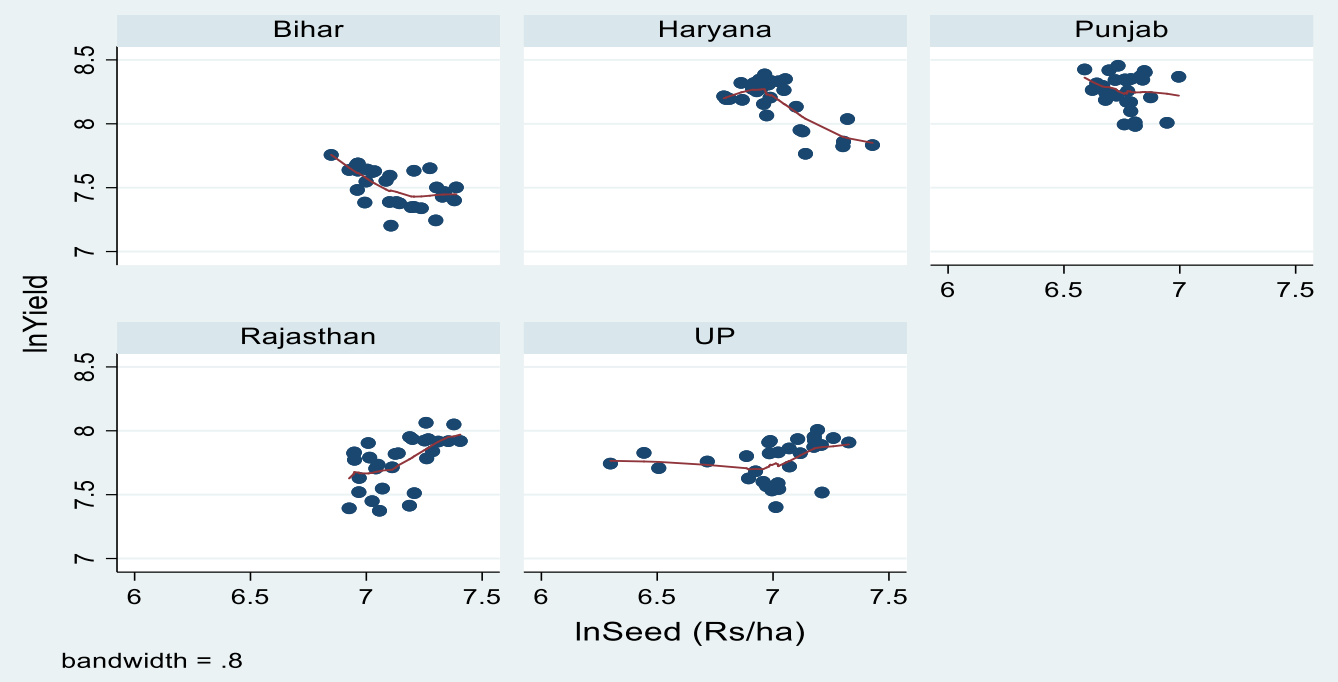

1

$2 \quad$ Fig 4 State wise lowess plot of yield and seed application 3 
Figures
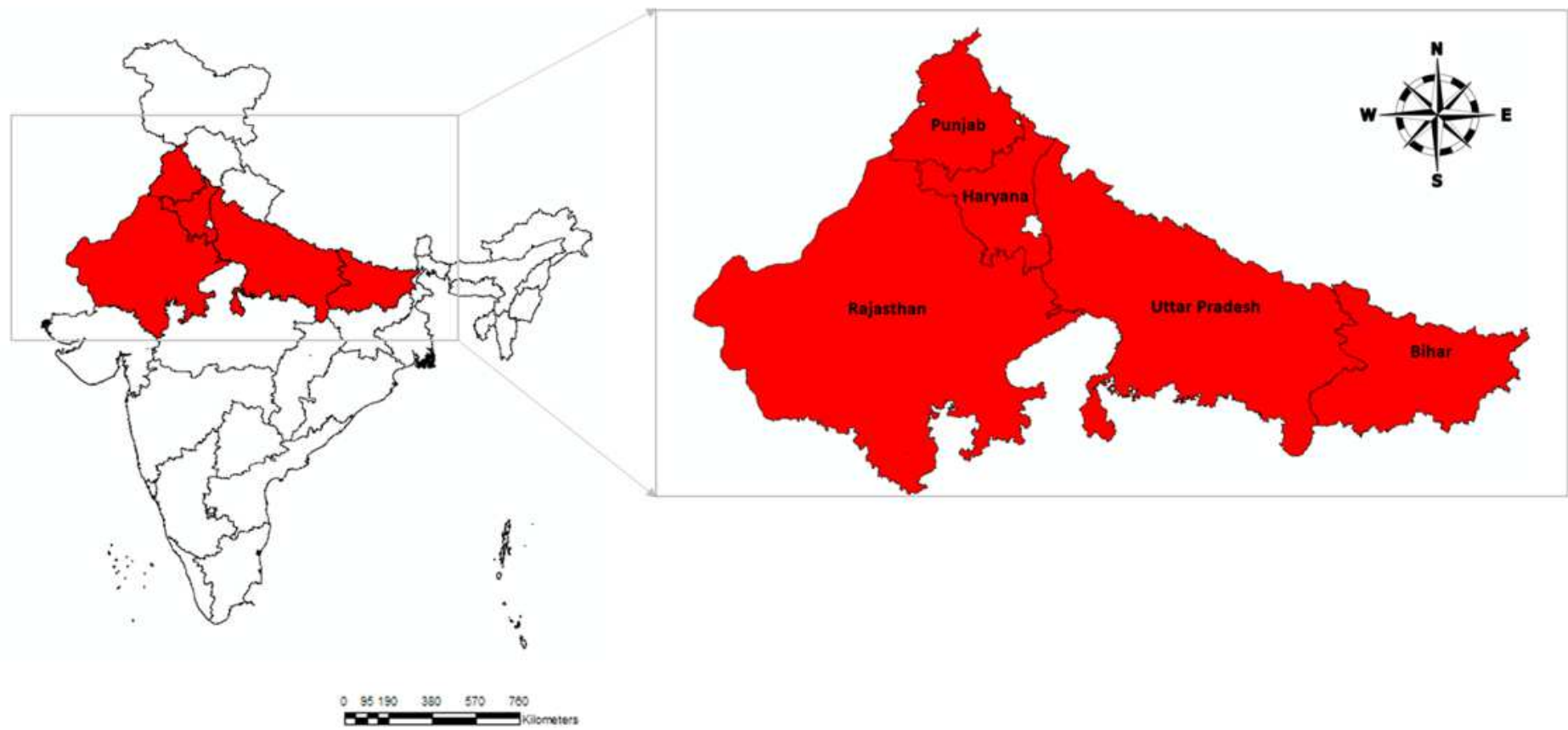

Figure 1

Map of study area

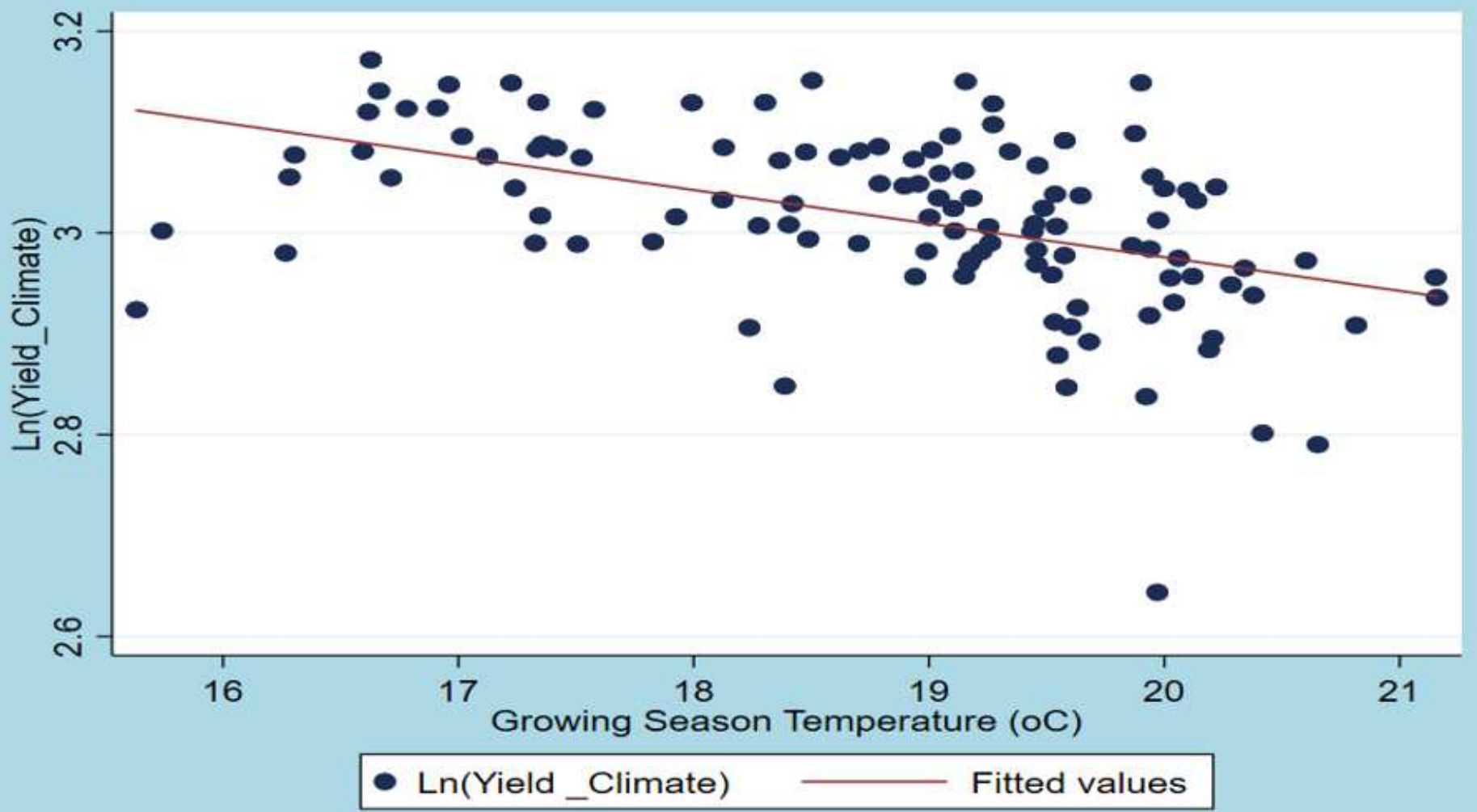


Figure 2

Correlation between GST and Yield climate

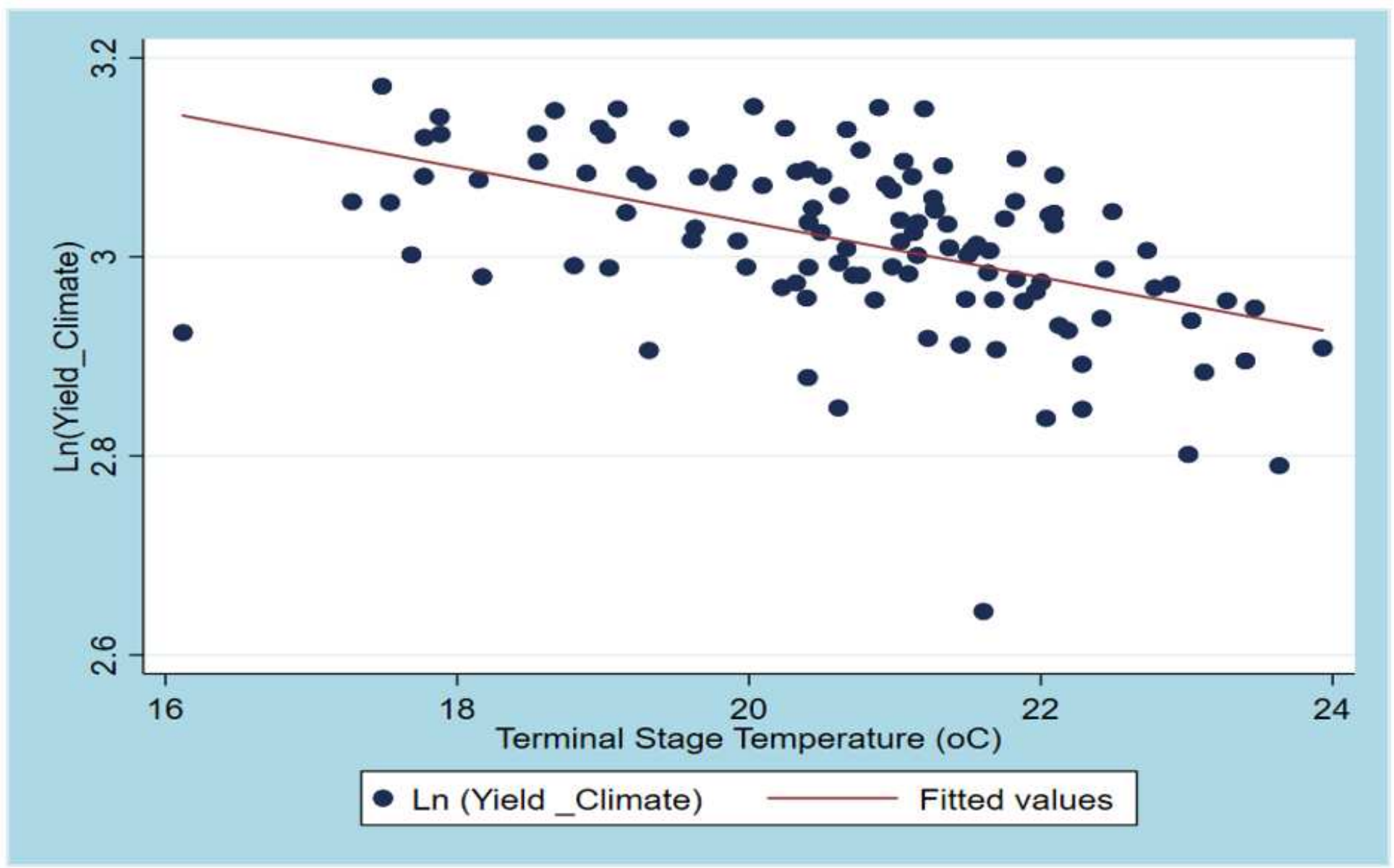

Figure 3

Correlation between TST and Yield climate 


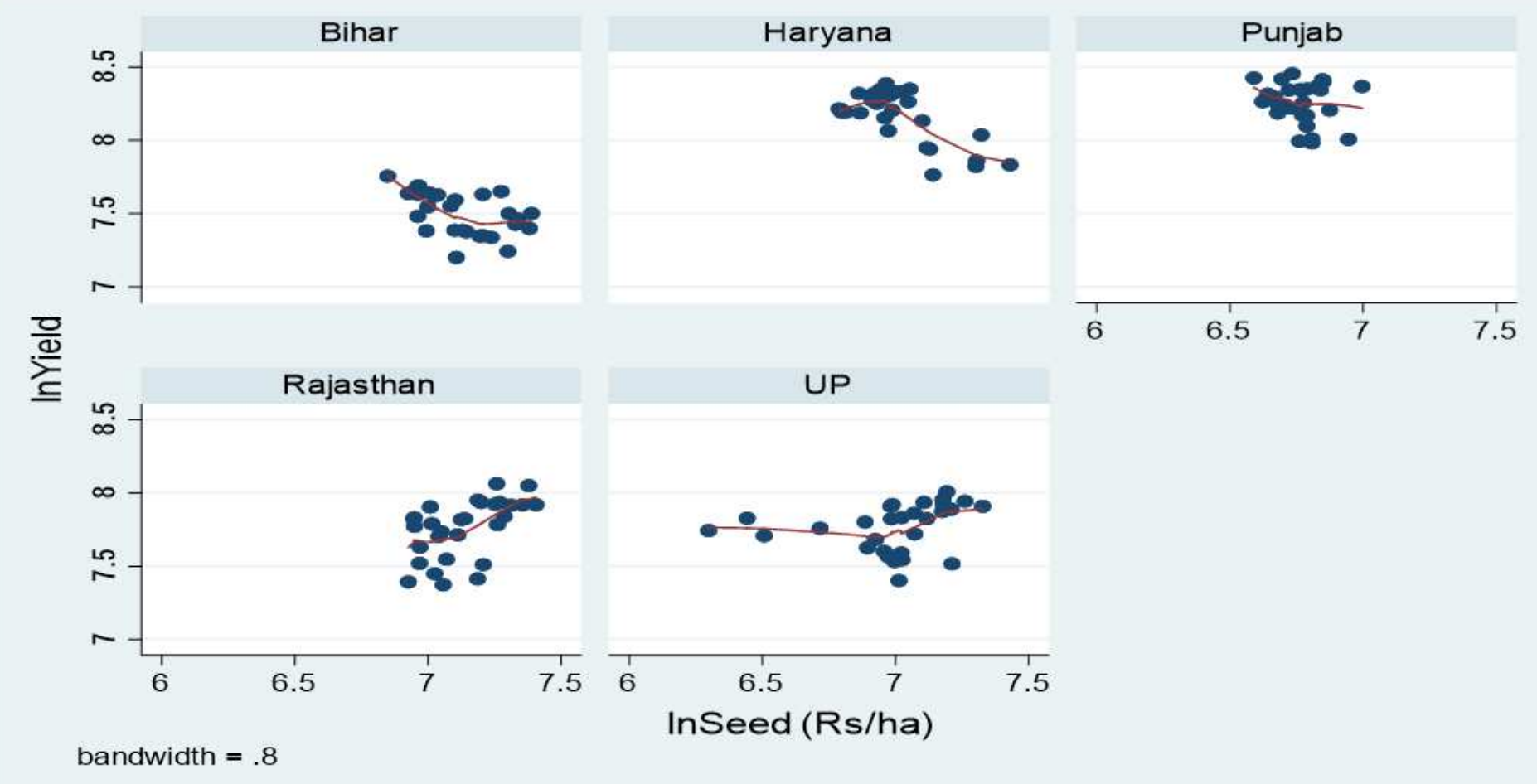

Figure 4

State wise lowess plot of yield and seed application 